\title{
Occurrence of a 16SrIV Group Phytoplasma not Previously Associated with Palm Species in Yucatan, Mexico
}

Roberto Vázquez-Euán, Centro de Investigación Científica de Yucatán, Mérida, Unidad de Biotecnología, Yucatán 97200, México; Nigel Harrison, University of Florida, Plant Pathology Department, Research and Education Center, Fort Lauderdale 33314; and María Narvaez and Carlos Oropeza, Centro de Investigación Científica de Yucatán, México

\begin{abstract}
Vázquez-Euán, R., Harrison, N., Narvaez, M., and Oropeza, C. 2011. Occurrence of a 16SrIV group phytoplasma not previously associated with palm species in Yucatan, Mexico. Plant Dis. 95:256-262.

The occurrence of 16 SrIV group phytoplasmas in palm species Sabal mexicana and Pseudophoenix sargentii is reported here for the first time. Palm trees showed leaf decay and leaf yellowing syndromes, respectively. An amplification product $(1.4 \mathrm{~kb})$ was obtained in symptomatic $S$. mexicana (18 of 21 ) and symptomatic $P$. sargentii (1 of 1$)$ palm trees sampled in different locations in Yucatan State, Mexico; five of the positive $S$. mexicana and the positive $P$. sargentii trees died. The identity of the phytoplasmas from these species was determined by restriction fragment length polymorphism profiling with restriction enzymes $A l u \mathrm{I}$ and HinfI, showing there could be two phytoplasma strains of the $16 \mathrm{SrIV}$ group. In one S. mexicana palm, the profile was the same as observed with these enzymes for phytoplasmas of 16SrIV-A

subgroup, previously associated with Cocos nucifera palm trees and, in the rest of the trees, including the $P$. sargentii palm, the profile was for phytoplasmas of the 16SrIV-D subgroup. These identities were supported by analyses of the amplicons obtained by nested polymerase chain reaction by nucleotide-nucleotide BLAST analysis. Geographical distribution of the association $S$. mexicana/16SrIV group phytoplasmas was found widely dispersed in Yucatan State. A potential role of $S$. mexicana palm trees as a permanent source of phytoplasma inoculum is suggested. In addition to $P$. sargentii, other palm species (Thrinax radiata and $C$. nucifera) coexisting with $S$. mexicana trees were also sampled and analyzed.
\end{abstract}

Phytoplasmas are plant-pathogenic bacteria of the class Mollicutes that inhabit plant phloem and insects. They are associated with diseases of several hundred plant species $(11,15,16,18)$. They are poorly characterized because they are nonculturable and difficult to isolate $(2,28)$, and characterization relies primarily on molecular methods. Hence, using polymerase chain reaction (PCR) assays, with primer pairs derived from 16S rDNA sequences and restriction fragment length polymorphism (RFLP) analysis and sequencing of the conserved 16S rRNA gene $(15,16)$, they have been classified in a monophyletic clade consisting of 18 groups and more than 40 subgroups (27). The 'Candidatus Phytoplasma' genus has been adopted for a formal classification of these bacteria (13).

The lethal yellowing (LY) disease that affects several palm species is associated with phytoplasmas classified within one of these groups, the 16SrIV group (19), comprising six subgroups: (i) 16SrIV-A, that includes the coconut LY phytoplasma ' $\mathrm{Ca}$. Phytoplasma palmae' associated with most of the palm species affected by LY; (ii) 16 SrIV-B, that includes a phytoplasma found in coconut in Tabasco near the Yucatan Peninsula; (iii) 16SrIV-C, that includes Tanzanian coconut LY phytoplasmas; (iv) 16SrIV-D, that includes Carludovica palmata phytoplasma (CPY) (3) and Phoenix canariensis, $P$. dactylifera, $P$. sylvestris, and Syagrus romanzoffiana with Texas phoenix decline (TPD) phytoplasma $(10,11)$; (v) 16SrIV-E subgroup, that includes phytoplasmas identified in coconuts in Dominican Republic (17) and ' $\mathrm{Ca}$. Phytoplasma castanae', associated with chestnut witches' broom disease in Korea (14); and, finally, (vi) 16SrIV-F, a novel subgroup that includes a phytoplasma strain discovered in Washingtonia robusta palm (8).

Sabal mexicana is a palm species that grows on the coastal plain of the Gulf of Mexico, from the southern part of the State of

Corresponding author: C. Oropeza, E-mail: cos@cicy.mx

Accepted for publication 31 August 2010.

doi:10.1094/PDIS-02-10-0150

(C) 2011 The American Phytopathological Society
Tamaulipas to the Yucatan Peninsula $(22,23)$. This palm is called "guano" by Mayan people, who use it in many ways; for instance, the tree is used as an ornamental plant in urban landscape, the trunk is used for rural construction, the leaves are used for house roofs, and different parts are used for handicrafts. Therefore, it is the main income source of many families and economically important in Mexico $(1,22)$. S. mexicana is a species reported as resistant to LY by McCoy et al. (19) and still there are no reports in the literature associating it with any $16 \mathrm{SrIV}$ group phytoplasmas. However, in 2004-2005, three S. mexicana palm trees in the Botanical Garden of Centro de Investigación Científica de Yucatán (CICY), in Yucatán, México, developed leaf decay symptoms and died soon after. Preliminary analysis of DNA from these palm trees using nested PCR, with primers specific for LY group phytoplasmas (10), resulted in positive detection. More S. mexicana palm trees have since acquired similar symptoms in CICY's premises and other sites in Yucatán.

Therefore, the purpose of the present study was to determine whether the symptoms in S. mexicana in CICY's botanical garden were caused by a 16SrIV group phytoplasma and, if so, characterize it, and determine whether the occurrence of this event was extended to other locations in Yucatan State and whether it had spread to palm trees of other species co-existing with infected $S$. mexicana palm trees.

\section{Materials and Methods}

Sampling and evaluation of palm trees. Tissue samples were collected from both $S$. mexicana palm trees showing pronounced leaf discoloration symptoms and from symptomless, presumably healthy palm trees. Trees were sampled by removing either portions of the newest, as-yet-unfurled (spear) leaf or shavings from the interior basal stem using a portable electric drill as previously described (9). Samples were obtained during the course of surveys at four sites in Yucatan State in which affected palm trees were evident during 2004 to 2008. They included the Botanical Garden at CICY in Merida, Periferico urban landscapes in Merida (approximately $10 \mathrm{~km}$ from CICY), Chicxulub Puerto (40 km north of Merida), and Ticul (100 km south of Merida). Basal stem samples 
were removed from coconut (Cocos nucifera), green thatch palm (Thrinax radiata), and Buccaneer palm (Pseudophoenix sargentii), with or without foliar yellowing symptoms, that were growing in close proximity to symptomatic $S$. mexicana trees. In order to monitor symptom progression on $S$. mexicana, sites were revisited on a monthly basis for 18 months to collect data on numbers of green leaves, fruit, and inflorescence present on symptomatic and symptomless trees. The data were analyzed using a $t$ student test to evaluate the statistical significance between treatments $(95 \%$ confidence interval, $\alpha=0.05$ ).

DNA extraction and PCR assay. Samples $(3 \mathrm{~g})$ of leaf or stem tissues were ground separately to a fine powder in liquid nitrogen using a mortar and pestle. Nucleic acids were then extracted from the pulverized tissues by the cetyltrimethylammonium bromide method of Doyle and Doyle (5). Aliquots of each final preparation resuspended in Tris-EDTA buffer $(10 \mathrm{mM}$ Tris, $1 \mathrm{mM}$ EDTA, $\mathrm{pH}$ 8) were electrophoresed through standard 1\% agarose gels using Tris-acetate-EDTA (TAE; $40 \mathrm{mM}$ Tris-acetate, $1 \mathrm{mM}$ EDTA) as running buffer. DNA in gels was stained with ethidium bromide (EtBr), then visualized by UV transillumination and photographed.

DNA samples were each diluted 1:10, 1:100 and 1:1000 with sterile deionized water and $5 \mu \mathrm{l}$ of each dilution was used as template in a nested PCR assay following a previously described protocol (10). Briefly, initial amplifications (35 cycles) were performed in $50-\mu$ l reaction mixtures employing phytoplasma universal rRNA operon primer pairs P1 (4) and P7 (24). Resulting products were diluted 1:20 or 1:40 with sterile deionized water, and $5 \mu \mathrm{l}$ of each dilution was then reamplified (35 cycles) with 16SrIV group-specific primer pair LY16Sf (5'-CATGCAAGT CGAACGGAAATC-3') and LY16Sr (5'-GCTTACGCAGTTAGG CTGTC-3') (10). Aliquots $(10 \mu \mathrm{l})$ of final reaction products were electrophoresed through $1 \%$ agarose gels in TAE buffer and visualized as described above.

Analysis of PCR products. Aliquots of nested PCR products (5 $\mu \mathrm{l})$ were subjected to separate digestion with $A l u \mathrm{I}$, HhaI, or HinfI restriction endonucleases at $37^{\circ} \mathrm{C}$ for a minimum of $16 \mathrm{~h}$. Products of digests were separated by electrophoresis through $8 \%$ nondenaturing polyacrylamide gels using Tris-borate-EDTA $(90 \mathrm{mM}$ Trisborate, $2 \mathrm{mM}$ EDTA) as running buffer. DNA fragment profiles in gels were stained with $\mathrm{EtBr}$ and recorded as described above.

Sequencing and phylogenetic analysis of cloned rDNA products. Residual nested PCR products purified from $0.7 \%$ agarose gels using a DNA Gel extraction kit (Millipore Corp., Bedford, MA) were ligated with vector pGEM-T (Promega Corp., Madison, WI) and propagated in Escherichia coli XL1 Blue cells (Stratagene, La Jolla, CA) according to the manufacturer's instructions. Recombinant plasmids were isolated from individual clones using a Plasmid Midiprep kit (Qiagen, Hilden, Germany). Cloned inserts were sequenced in full by a commercial service (Davis Sequencing, Inc., Davis, CA). To minimize potential sequencing errors, each insert was sequenced two or three times.

A database search of homologous sequences was performed by Blast analysis at the National Center for Biotechnology Information (NCBI) website (http://ncbi.nlm.nih.gov/BLAST). Phylogenetic interrelationships among palm-associated phytoplasmas, representatives of other phytoplasma groups (12), and Achole-

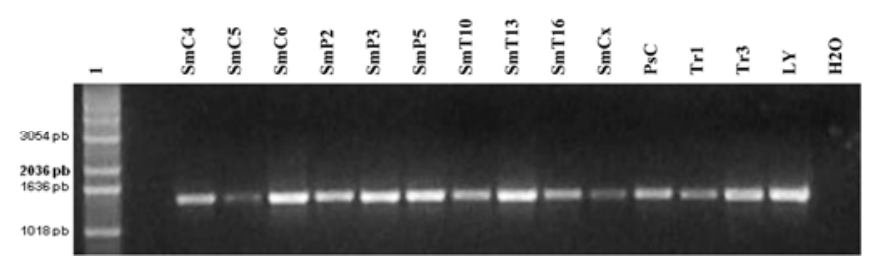

Fig. 1. Amplification of phytoplasma $16 \mathrm{~S}$ rDNA from Sabal mexicana (Sm), Pseudophoenix sargentii (Ps), Thrinax radiata (Tr), and Cocos nucifera $(\mathrm{Cn})$ by a nested polymerase chain reaction assay employing phytoplasma universal rRNA operon primer pair P1/P7 followed by LY16Sf/LY16Sr. $\mathrm{H}_{2} \mathrm{O}=$ negative control; $1=1-\mathrm{kb}$ DNA ladder. plasma palmae were assessed based on partial 16S rRNA gene sequences $(1,308 \mathrm{bp})$. Sequences were aligned using ClustalW (26). A neighbor-joining tree was constructed from the aligned sequences using MEGA 4.0.1 software (25). A. palmae was used as the outgroup to root the tree.

\section{Results}

Phytoplasma detection. The nested PCR assay yielded a 1.4-kb fragment of phytoplasma 16S rDNA from a total of 18 of 21 $(85.7 \%)$ diseased S. mexicana trees assayed from different locations in Yucatan State (Fig. 1). In the Botanical Garden at CICY, two mature bearing $S$. mexicana trees with foliar decay symptoms were first observed in 2004 and a third developed similar symptoms during late 2005. All three palm trees tested phytoplasma positive and eventually died. An additional 18 bearing palm trees that included 5 with and 13 without symptoms were subsequently sampled at this site during 2006 and 2007. Phytoplasma infection of all 5 symptomatic trees was confirmed by nested PCR assay and 1 of these eventually died whereas all 13 symptomless trees produced negative results and have remained alive. Similarly, at Ticul, three of six $(50 \%)$ mature $S$. mexicana trees with symptoms were found to contain phytoplasmas and one has since died whereas phytoplasmas were undetectable in all eight mature palm trees lacking symptoms. In Chicxulub, only one mature palm with symptoms was observed during 2008. Although this palm tested positive for phytoplasma infection, it did not decline and die during the 3 years of the course of this study. In Periferico, Mérida, where 17 young, nonbearing trees were assayed for phytoplasma infection during 2006 and 2007, phytoplasmas were found in all 6 palm trees exhibiting prominent foliar discoloration symptoms, although none had died by the end of this study. Phytoplasmas remained undetected in the other 11 young palm trees that were symptomless and that did not develop symptoms during the following 2 years.

Other palm species that were co-existing with $S$. mexicana were also studied. In the Botanical Garden at CICY, a symptomatic $P$. sargentii palm with leaf yellowing symptoms was observed during 2006; it tested positive for phytoplasmas and died, whereas five symptomless $P$. sargentii palm trees at this location produced uniformly negative results when analyzed by nested PCR. Furthermore, at this same location, two $T$. radiata palm trees with foliar yellowing proved to be phytoplasma positive, one of which subsequently died (Fig. 1), whereas all seven additional symptomless $T$. radiata trees that were examined at this location produced uniformly negative results.

In Chicxulub, three of seven $(42.8 \%)$ T. radiata palm trees with leaf yellowing symptoms were found to be PCR positive for phytoplasmas and one of these trees subsequently died. Of the four $C$. nucifera palm trees found with foliar yellowing symptoms (three at Ticul and one at Chicxulub), only one palm at Ticul was phytoplasma positive although all four trees eventually died. The solitary diseased palm observed at Chicxulub was phytoplasma positive, too, and died. All seven $C$. nucifera without symptoms sampled at CICY for comparative purposes proved to be phytoplasma negative. Results of palm species evaluations for phytoplasma infection are summarized in Table 1.

Phytoplasma identification and characterization. Restriction fragment patterns generated by $H$ haI digestion of $16 \mathrm{~S}$ rDNA products amplified by nested PCR revealed no apparent differences among phytoplasmas detected in S. mexicana or in P. sargentii, $T$. radiata, and $C$. nucifera. (Fig. 2). However, AluI or HinfI digests each revealed two distinct fragment profiles among palm trees. One profile was associated with 14 of $15 \mathrm{~S}$. mexicana palm trees, a $P$. sargentii palm, and one of two $T$. radiata trees while a second profile was associated with $C$. nucifera and one $T$. radiata palm sampled at CICY as well as one S. mexicana palm sampled at Chicxulub (Fig. 2).

Of the $16 \mathrm{~S}$ rDNA sequences derived by nested PCR from 13 diseased palm trees, 12 from $S$. mexicana (6 from CICY, 3 from Periferico, and 3 from Ticul) and one from $P$. sargentii were all virtually identical, differing by one or two bases only. Pairwise 
comparison of sequences by Blast analysis indicated that all 13 sequences were most similar (99.4 to $100 \%$ ) to that of TPD phytoplasma, a subgroup 16SrIV-D strain (GenBank accession no. AF434989). By comparison, sequences from S. mexicana palm SmCx (Chicxulub), C. nucifera (Ticul), and T. radiata palm $\operatorname{TrC} 2$ (CICY) were most similar (99.9, 99.9, and 99.8\%, respectively) to that of coconut LY phytoplasma (Juno-C2, accession no. AF498309), a known subgroup 16SrIV-A strain from Florida.

Phylogenetic analyses of $16 \mathrm{~S}$ rDNA from representative phytoplasmas detected in $S$. mexicana and other palm species during this study all clustered together with other members of the coconut lethal yellows phytoplasma subclade (6) (Fig. 3). Tree branching patterns indicated that phytoplasma strains infecting $S$. mexicana from Ticul (GU473588), P. sargentii (GU473591), and T. radiata from CICY ( $\operatorname{Tr} 1$ GU473586) clustered together with other subgroup 16SrIV-D phytoplasma strains that included TPD and CPY whereas phytoplasma strains infecting the $S$. mexicana from Periferico (GU473585) and CICY (GU473587) were identical, sharing a single sub-branch, suggesting that they might represent a new subgroup within the coconut lethal yellows group. Sequences of phytoplasma strains infecting C. nucifera at Ticul (GU473590) and Chicxulub and T. radiata ( $\operatorname{Tr} 2$ GU473592) from CICY, as well as $S$. mexicana at Chicxulub (GU473589), clustered together with the coconut LY phytoplasma strains from Florida and other members of subgroup 16SrIV-A (Fig. 3).

Symptom progression on $\boldsymbol{S}$. mexicana. The most pronounced symptom overall in the foliar decay on mature, bearing $S$. mexicana palm trees was discoloration, necrosis, and loss of older leaves (Fig. 4A and B) which, at the outset, was essentially indistinguishable from that of natural leaf senescence associated with this palm species. However, as the disease developed, there was an increasing proportion of decaying and dying leaves compared with noninfected trees, progressively affecting younger leaves in the mid-crown and upper crown (Fig. 4C and D), finally leaving the palm without leaves. Although leaf decay was occurring, inflorescence and fruit production was also affected. Inflorescences that were already developed produced a decreased number of fruit (Fig. 4E) whereas those inflorescences that were developing showed atrophy, with smaller size and no fruiting at all (Fig. 4F). This symptom progression in adult bearing trees took more than 2 years, ending with the death of the palm.

Excessive foliar discoloration similar in appearance of that associated with mature diseased S. mexicana was also found on small, immature palm trees at Periferico in Merida, a site where mature $S$. mexicana trees were absent (Fig. $4 \mathrm{H}$ and I). All six palm trees with symptoms sampled at this site were judged to contain group 16SrIV phytoplasmas. However, phytoplasmas were not detected in any of the 11 other palm trees without discernible symptoms that were sampled at this site. Furthermore, during 3 years of periodic monitoring of the six infected trees, only one palm was observed to die, although leaf discoloration persisted on the remaining palm trees (Table 1).

When leaf, inflorescence, and fruit production were analyzed quantitatively on a monthly basis during an 18-month period, significant differences between known infected and uninfected mature palm trees were evident (Fig. 5). The average monthly number of green leaves supported by uninfected palm trees was $14.3 \pm 0.68$ whereas phytoplasma-infected palm trees retained $9.8 \pm 0.80$ green leaves, a significantly lower number $(P=0.05)$. Similarly, the number of fruit per inflorescence on uninfected trees was 4,850 \pm 1,184 , whereas the lower value of 2,212 \pm 801 for infected trees was significantly different $(P=0.05)$. The measured decrease in the numbers of fruit per inflorescence appears to be a developmental response to infection by subgroup 16SrIV-D phytoplasmas rather than a result of natural fruit abortion which was not observed to occur in uninfected $S$. mexicana trees. In a related observation, the number of inflorescences that developed on each uninfected palm was $6.5 \pm 0.58$ and was significantly different $(P=0.05)$ from the value of $3.5 \pm 0.52$ obtained for infected palm trees. Furthermore, it is worth noting that none of the infected trees exhibiting symptoms from which this data were collected had died during the 18-month study period which ended in 2009, although foliar discoloration on these trees had continued to slowly intensify.

$P$. sargentii, T. radiata, or $C$. nucifera co-existing with $S$. mexicana in the Botanical Garden at CICY and at one or more of the other sampling sites showed evidence of pronounced leaf yellowing (Table 1). In the case of $P$. sargentii (Fig. 4J), symptom development was observed on only one palm and included fruit drop, excessive yellowing of leaves (Fig. 4K), and necrosis of inflores-

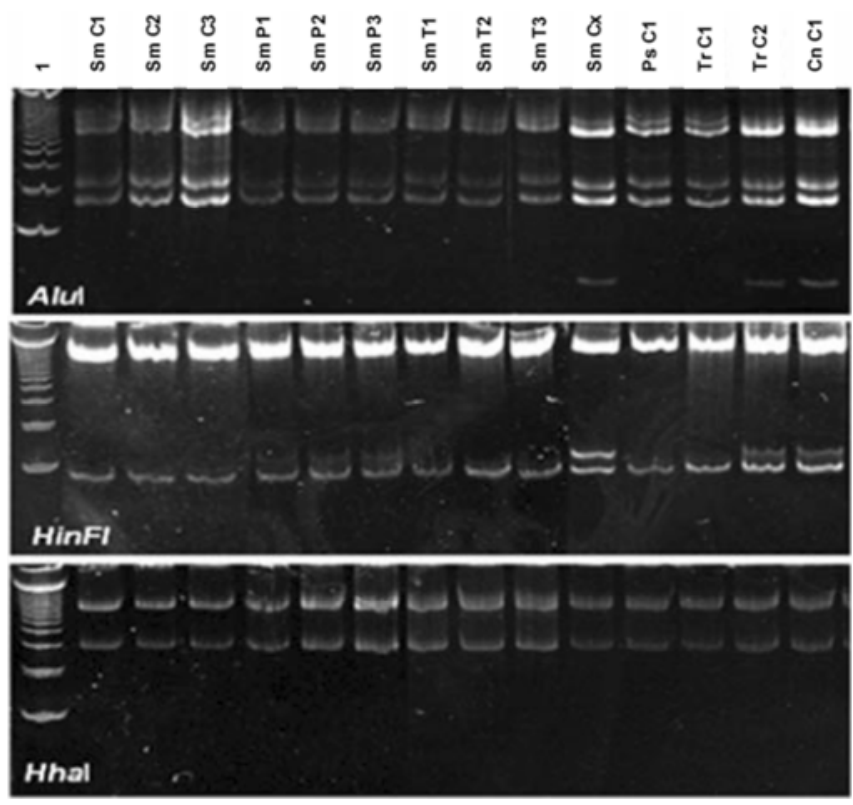

Fig. 2. Representative restriction fragment profiles of phytoplasmas $16 \mathrm{~S}$ rDNA amplified from symptomatic palm trees by a nested polymerase chain reaction (PCR) assay incorporating rRNA gene operon primer pairs P1/P7 followed by 16SrIV group-specific primer pair LY16Sf/LY16Sr. PCR products were derived from Sabal mexicana (Sm), Pseudophoenix sargentii (Ps), Thrinax radiata (Tr), and Cocos nucifera $(\mathrm{Cn})$ and digested with Alul, Hinfl, or Hhal endonuclease. $1=100-$ bp DNA ladder.

Table 1. Analysis of four palm species with and without foliar discoloration symptoms at four sites in Yucatan State, Mexico for evidence of phytoplasma infection by a nested polymerase chain reaction assay employing phytoplasma universal rRNA operon primer pair P1/P7 followed by 16 SrIV group-specific primer pair LY16Sf/LY16Sr

\begin{tabular}{|c|c|c|c|c|c|c|c|c|c|c|c|c|}
\hline \multirow[b]{3}{*}{ Location } & \multicolumn{12}{|c|}{ Palm trees with positive detection (+), dead, and total analyzed (with symptoms) } \\
\hline & \multicolumn{3}{|c|}{ Sabal mexicana } & \multicolumn{3}{|c|}{ Pseudophoenix sargentii } & \multicolumn{3}{|c|}{ Cocos nucifera } & \multicolumn{3}{|c|}{ Thrinax radiata } \\
\hline & + & Dead & Total & + & Dead & Total & + & Dead & Total & + & Dead & Total \\
\hline Mérida, CICY & 8 & 4 & $21(8)$ & 1 & 1 & $6(1)$ & 0 & 0 & $7(0)$ & 2 & 1 & $9(2)$ \\
\hline Mérida, Periférico & 6 & 0 & $17(6)$ & $\ldots$ & $\ldots$ & $\ldots$ & $\ldots$ & $\ldots$ & $\ldots$ & $\ldots$ & $\ldots$ & $\ldots$ \\
\hline Ticul & 3 & 1 & $14(6)$ & $\ldots$ & $\ldots$ & $\ldots$ & 1 & 3 & $3(3)$ & $\ldots$ & $\ldots$ & $\ldots$ \\
\hline Chicxulub & 1 & 0 & $1(1)$ & $\ldots$ & $\ldots$ & $\ldots$ & 1 & 1 & $1(1)$ & 3 & 1 & $7(7)$ \\
\hline Total & 18 & 5 & $53(21)$ & 1 & 1 & $6(1)$ & 2 & 4 & $11(4)$ & 5 & 2 & $16(9)$ \\
\hline
\end{tabular}

a Number of palm trees with symptoms is indicated in parentheses. The difference in the totals represents those palm trees without symptoms. 
cence and spathe tissues (Fig. 4L), followed by mortality. Presence of a 16SrIV group phytoplasma in this palm was confirmed by nested PCR assay. Of the nine T. radiata palm trees in the Botanical Garden at CICY, phytoplasma infections were confirmed in only two symptomatic palm trees; phytoplasmas were not detected in any of seven symptomless palm trees. Similarly, of seven $T$. radiata trees with leaf yellowing sampled at Chicxulub, three subsequently tested phytoplasma positive. Among infected trees, mortality of one palm only occurred at each site. Although symptoms observed on three $C$. nucifera palm trees at Ticul and a single palm located at Chicxulub were typical of those described for LY disease by Zizumbo et al. (29), phytoplasmas were detected in only one palm at each location. All four trees sampled at these two locations died during the course of this study (Table 1).

\section{Discussion}

The occurrence of phytoplasmas of the 16SrIV group have been reported in several palm species (19); however, in some species, such as $S$. mexicana and $P$. sargentii, infection by these phytoplasmas or any other type have not been reported previously in the scientific literature. The main focus of this study was $S$. mexicana and the phytoplasmas invading it; however, other palm species $(P$. sargentii, T. radiata, and $C$. nucifera) that were coexisting with $S$. mexicana palm trees and showed leaf decay syndromes were also studied, with the intention of learning whether phytoplasmas were present and, if so, were the same or different strains. Palm trees studied included asymptomatic individuals because a previous report showed the occurrence of $16 \mathrm{SrIV}$ group phytoplasmas in asymptomatic $T$. radiata and $C$. readii palm trees (20). Here, we

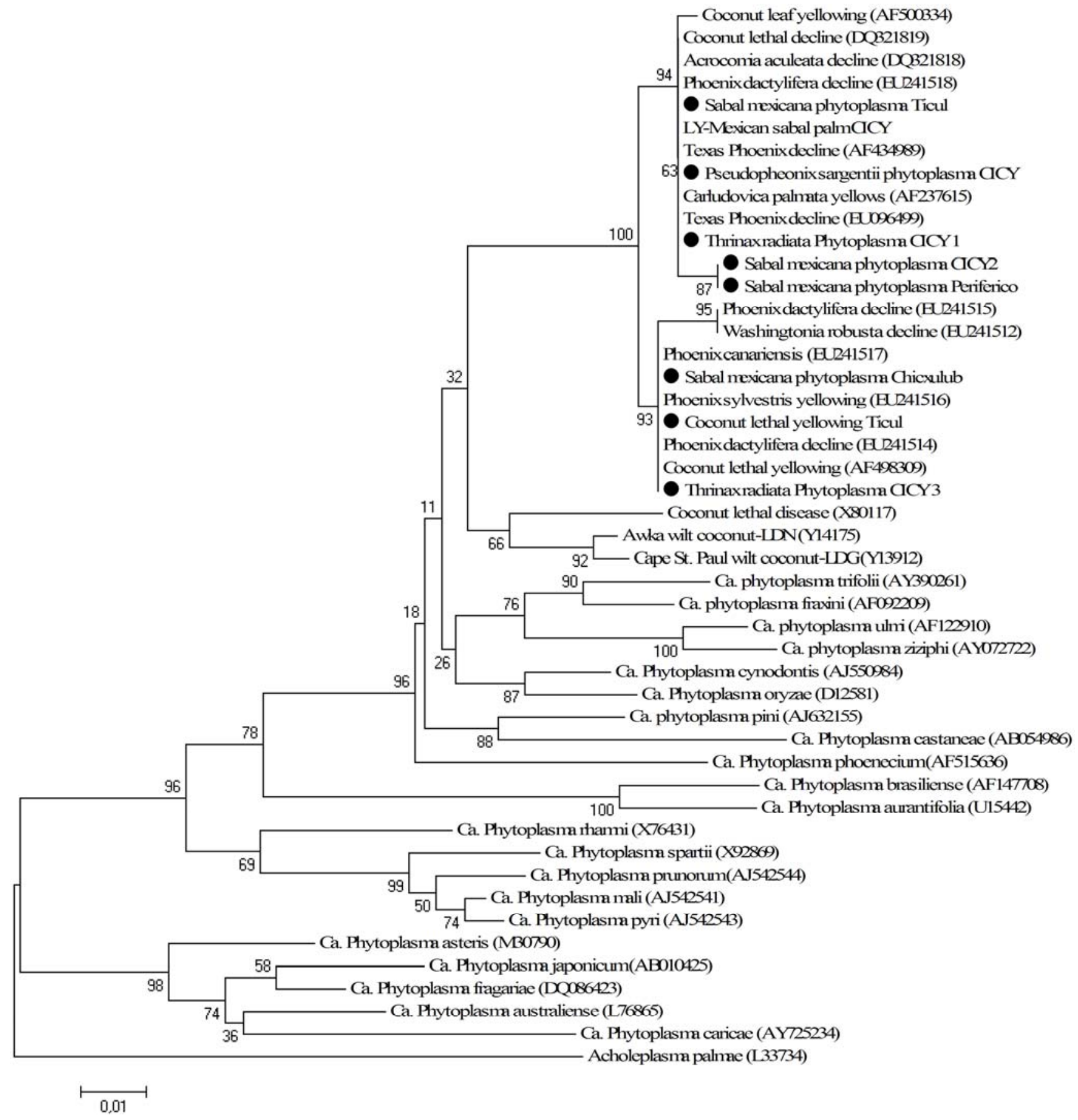

Fig. 3. Phylogenetic tree of $16 \mathrm{~S}$ rRNA gene sequences from representative phytoplasmas in the coconut lethal yellows (16SrIV) group and other phytoplasma groups constructed by the neighbor-joining method. Phytoplasma strains sequences in this study are indicated by a black circle $(\bullet)$. Bootstrap values (used as an indicator of the reliability of the analysis) are shown on branches. 

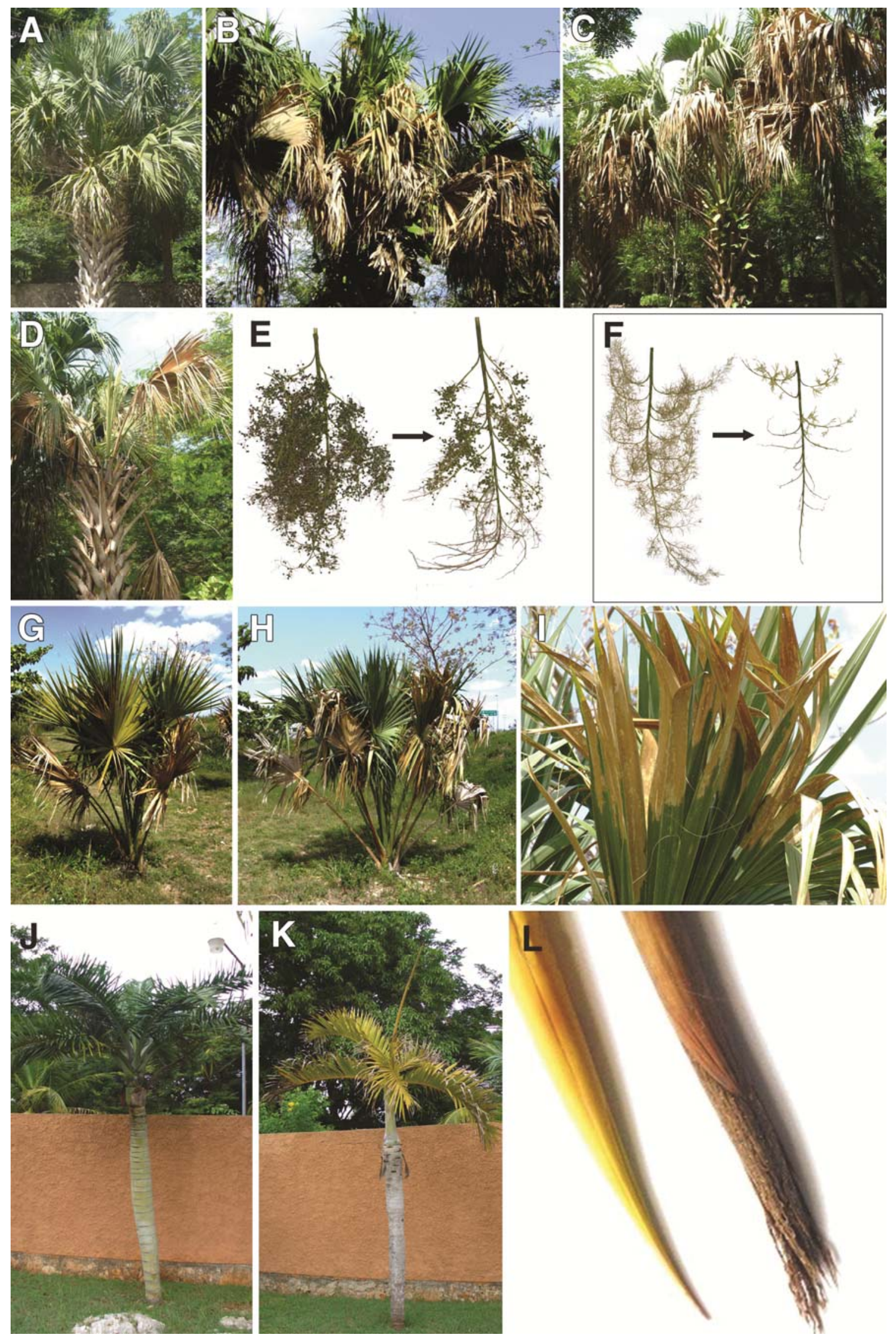

Fig. 4. Appearance and progression of foliar decay symptoms on Sabal mexicana infected with group 16SrIV phytoplasmas. A, Palm tree lacking discernible symptoms showing mostly green leaves; B, foliar discoloration starting on basal, older leaves; C, progressive discoloration of younger leaves in the mid- and upper crown; D, loss of most leaves from the crown prior preceding palm mortality; and $\mathbf{E}$, reduction in fruit development on $\mathbf{F}$, an inflorescence showing atrophy. $\mathbf{G}$ and $\mathbf{H}$, Foliar decay symptoms in young $S$. mexicana palm trees infected with lethal yellowing phytoplasmas; I, detail. J-L, Foliar symptoms associated with phytoplasma infection of Pseudophoenix sargentii. $\mathbf{J}$, Uninfected palm; K, infected palm; and L, yellow coloration of inflorescence sheath from an uninfected palm contrasting with the discolored sheath and emerging inflorescence from an infected palm. 
report for the first time that $S$. mexicana and $P$. sargentii palm trees affected by leaf decay syndromes were associated with $16 \mathrm{SrIV}$ group phytoplasmas, as evidenced by nested PCR, RFLP assays, and nucleotide sequence analysis.

The symptoms observed in $S$. mexicana were similar to those caused by TPD (GenBank accession no. AF434989) in Phoenix canariensis, $P$. dactylifera, $P$. sylvestris, and Syagrus romanzoffiana $(8,10)$. In $C$. nucifera, symptoms were similar to those already described in the literature (29). In the case of Pseudophoenix sargentii (spotted in only one single palm) and $T$. radiata, symptoms observed were the typical symptoms of LY disease, as were those reported for $C$. nucifera. Therefore, two patterns of symptoms were observed, one for Sabal mexicana and the other for P. sargentii, $T$. radiata, and $C$. nucifera, which seem to be independent of the type of phytoplasma infecting.

The identity of the phytoplasmas isolated from S. mexicana was studied. RFLP profiles obtained with restriction enzymes $A l u \mathrm{I}$ and HinfI showed that it could be hosting two phytoplasma strains of the $16 \mathrm{SrIV}$ group. In one case, profiles were the same observed for these enzymes for LY-Fla phytoplasmas and 16SrIV-A subgroup $(7,20)$; and, in the second case, for TPD and CPY phytoplasmas and the 16SrIV-D subgroup (10). The first one was found in only 1 of the 10 positive $S$. mexicana palm trees analyzed (GU473589). In the other nine trees, profiles were of subgroup D and coexistence of both strains was not found in any of the palm trees analyzed. These identities were supported by analyses of the amplicons obtained by nested PCR by nucleotide-nucleotide BLAST alignments using the NCBI database. However, phylogenetic analysis showed one more strain group for phytoplasmas from an $S$. mexicana palm at CICY (GU473585) and one at Periferico (GU473587), both clustered together in one separate branch, and then probably representing a new 16 SrIV subgroup. The results also suggest that there is a more frequent association of subgroup D phytoplasmas than subgroup A phytoplasmas with $S$. mexicana palm trees, and that the 16 SrIV group phytoplasmas can invade young and adult $S$. mexicana trees.

When analysis of samples from other palm species with leaf decay symptoms that were co-existing with $S$. mexicana palm trees was carried out, $16 \mathrm{SrIV}$ group phytoplasmas were also detected in them. In CICY's Botanical Garden, we found a T. radiata palm with 16 SrIV-A phytoplasmas but also another $T$. radiata palm and a $P$. sargentii palm with $16 \mathrm{SrIV}-\mathrm{D}$ phytoplasmas the same as those found in S. mexicana trees. Occurrence of $16 \mathrm{SrIV}$-A phytoplasmas in $T$. radiata has already been reported, although in asymptomatic palm trees (20), but the 16SrIV-D phytoplasmas have not been reported before in this species; neither these phytoplasmas nor any other in P. sargentii palm trees. Therefore, these results show that
16SrIV-D phytoplasmas can be hosted by different palm species in Yucatan State. How extensive this could be in the species studied and whether it occurs in others remains to be determined. Interestingly, a $C$. nucifera palm and an S. mexicana palm in Ticul located at about $10 \mathrm{~m}$ from each other were infected by $16 \mathrm{SrIV}$ group phytoplasmas but, in the first palm, it was subgroup A and, in the second palm, subgroup $\mathrm{D}$, an observation that is consistent with the fact that, in Yucatan State, C. nucifera palm trees have been associated only with subgroup A phytoplasmas and never with subgroup D phytoplasmas. However, in the case of the Mexican Pacific Coast, C. nucifera trees have been associated with subgroup D phytoplasmas (7). Therefore, it will be important to carry out a more extensive survey of phytoplasmas occurring in $C$. nucifera trees in Yucatan State to determine whether subgroup D phytoplasmas can also be found in this species and, if that occurs, what the significance could be.

Regarding the source of the S. mexicana 16SrIV-D phytoplasmas, we may speculate about two possible origins. One could be related to the TPD phytoplasmas found in Texas and Florida $(8,10)$ because there is a very high homology between $S$. mexicana 16SrIV-D phytoplasmas and TPD phytoplasmas. We can also consider the CPY phytoplasmas isolated from C. palmata plants (3), because there is also a very high homology between $S$. mexicana 16SrIV-D phytoplasmas and CPY phytoplasmas. The original CPY phytoplasma outbreak was reported in Calkini, Campeche (3), a location close to Ticul, one of the sites where $S$. mexicana trees were found to be infected by 16 SrIV-D phytoplasmas. Therefore, the last possibility could be more likely because of the geographic proximity. Also, it is important to consider that the development of symptoms in $S$. mexicana infected by $16 \mathrm{SrIV}-\mathrm{D}$ phytoplasmas is lengthy and the mortality is low according to casual observations during sampling in different sites, suggesting that the subgroup 16SrIV-D phytoplasma is a native strain rather than an exotic strain.

In the case of the $16 \mathrm{SrIV}-\mathrm{A}$ phytoplasma found in a single $S$. mexicana palm in Chicxulub, it might have been transmitted from other palm species in this location that were affected by this phytoplasma, such as $T$. radiata and $C$. nucifera. How 16 SrIV-A and 16SrIV-D phytoplasmas could be vectored into $S$. mexicana palm trees was not studied but Myndus crudus, the cixiid vector of LY (12), was found visiting $S$. mexicana trees in all the locations studied; therefore, it would be important to consider this insect for future evaluation as vector of the phytoplasma strains found in $S$. mexicana and other palm species reported here. This also might explain the geographic spread of the association of 16SrIV group phytoplasmas with S. mexicana. This association was found in CICY's premises in Merida; in Periferico, also in Merida about 10

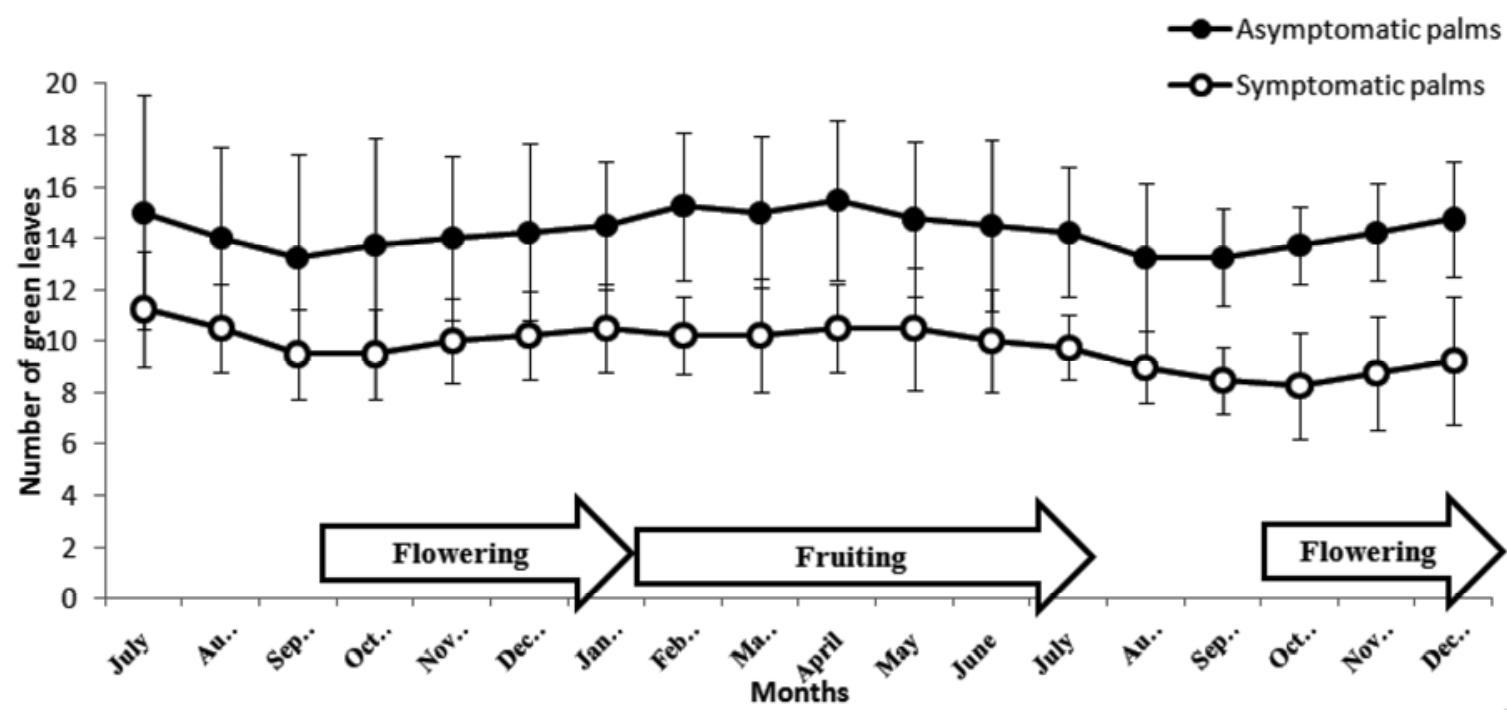

Fig. 5. Average number of green leaves on phytoplasma-infected and uninfected Sabal mexicana over an 18-month period $(n=4)$. 
$\mathrm{km}$ away; and in Chicxulub and Ticul, located $40 \mathrm{~km}$ north and $100 \mathrm{~km}$ south respectively, of Merida. No further locations were explored but, considering what was found, it is reasonable to assume that a wider distribution could be possible because $S$. mexicana, together with $P$. sargentii, Cocothrinax readii, and $T$. radiata, are palm species widely distributed along the coasts of the Yucatan Peninsula (23). Then, as previously proposed for $C$. readii and $T$. radiata $(20,21), S$. mexicana trees might be considered to be a potential permanent source of 16SrIV phytoplasmas inoculum and, thus, a threat to Cocos nucifera and other palm species in Yucatan State. This is based on the following: (i) S. mexicana trees are widely distributed along the Yucatan Peninsula coasts; (ii) the 16SrIV-A and 16SrIV-D subgroup phytoplasmas (and probably another one) have been found in S. mexicana trees; (iii) this association is widely distributed geographically; and (d) although some palm trees were positive ( 18 of 21 symptomatic) and some died ( $n$ $=5$ ), most $S$. mexicana trees in locations were not affected. Also, the finding of $16 \mathrm{SrIV}-\mathrm{D}$ subgroup phytoplasmas in $T$. radiata and $P$. sargentii palm trees opens the possibility that these palm species could also be sources of inoculum of these phytoplasmas in Yucatan. Therefore, it will be necessary to continue researching these associations of $16 \mathrm{SrIV}$ phytoplasmas with $S$. mexicana and the other palm species to fully understand their importance as permanent sources of inoculum of phytoplasmas, and how extensive a threat they might pose to palm trees of social and economic importance such as $C$. nucifera.

\section{Acknowledgments}

We thank CONACYT (México, clave 185733) for a scholarship for R. Vázquez-Euán and Common Fund for Commodities (Stadhouderskade 1072 AB Amsterdam, FIGOOF/22) for partial support of the research reported here.

\section{Literature Cited}

1. Caballero, J., Martínez, A., and Gama, V. 2002. El uso y manejo tradicional de la palma de guano en el área maya de Yucatán. Biodiversitas 39:1-6.

2. Christensen, N., Axelsen, K., Nicolaisen, M., and Schulz, A. 2005. Phytoplasmas and their interactions with hosts. Trends Plant Sci. 10:526-535.

3. Cordova, I., Oropeza, C., Almeyda, H., and Harrison, N. 2000. First report of a phytoplasma-associated leaf yellowing syndrome of palma jipi plants in southern Mexico. Plant Dis. 84:807.

4. Deng, S., and Hiruki, C. 1991. Amplification of 16S rRNA genes from culturable and non-culturable mollicutes. J. Microbiol. Methods 14:53-61.

5. Doyle, J., and Doyle, J. 1990. Isolation of plant DNA from fresh tissue. Focus 12:13-15.

6. Gundersen, D., Lee, I., Rehner, S., Davis, R., and Kingsbury, D. 1994. Phylogeny of mycoplasmalike organisms (phytoplasmas): a basis for their classification. J. Bacteriol. 176:5244-5254.

7. Harrison, N., Cordova I., Richardson P., and Dibonito, R. 1999. Detection and diagnosis of lethal yellowing. Pages 183-196 in: Current Advances in Coconut Biotechnology. C. Oropeza, J. Verdeil, G. Ashburner, R. Cardeña, and J. Santamaría, eds. Kluwer Academic Publishers, Dordrecht, The Netherlands.

8. Harrison, N., Helmick, E., and Elliott, M. 2008. Lethal yellowing-type diseases of palms associated with phytoplasmas newly identified in Florida, USA. Ann. Appl. Biol. 153:85-94.

9. Harrison, N., Richardson, P., Kramer, J., and Tsai, J. 1994. Detection of the phytoplasma associated with lethal yellowing disease of palms in Florida by polymerase chain reaction. Plant Pathol. 43:998-1008.

10. Harrison, N., Womack, M., and Carpio, M. 2002. Detection and characterization of a lethal yellowing (16SrIV) group phytoplasma in Canary Island date palms affected by lethal decline in Texas. Plant Dis. 86:676-681.

11. Hogenhout, S., Oshima, K., Ammar, E., Kakizawa, S., Kingdom, H., and Namba, S. 2008. Phytoplasmas: bacteria that manipulate plants and insects. Mol. Plant Pathol. 9:403-423.

12. Howard, F. 1995. Lethal yellowing vector studies. I. Methods of experimental transmission. Pages 43-57 in: Lethal Yellowing Research and Practical Aspects. C. Oropeza, J. Verdeil, G. R. Ashburner, R. Cardeña, and J. M. Santamaria, eds. Kluwer Academic Publishers, Dordrecht, The Netherlands.

13. IRPCM. 2004. 'Candidatus Phytoplasma', a taxon for the wall-less, nonhelical prokaryotes that colonize plant phloem and insects. Int. J. Syst. Evol. Microbiol. 54:1243-1255.

14. Jung, H., Sawayanagi, T., Kakizawa, S., Nishigawa, H., Miyata, S., Oshima, K., Ugaki, M., Lee, J., Hibi, T., and Namba, S. 2002. 'Candidatus Phytoplasma castaneae', a novel phytoplasma taxon associated with chestnut witches' broom disease. Int. J. Syst. Evol. Microbiol. 52:1543-1549.

15. Lee, I., Davis, R., and Gundersen-Rindal, D. 2000. Phytoplasma: phytopathogenic Mollicutes. Annu. Rev. Microbiol. 54:221-255.

16. Lee, I., Gundersen-Rindal, D. and Bertaccini, A. 1998. Phytoplasma: ecology and genomic diversity. Phytopathology 88:1359-1366.

17. Martinez, R., Narvaez, M., Fabre, S., Harrison, N., Oropeza, C., Dollet, M. and Hichez, E. 2008. Coconut lethal yellowing on the Southern Coast of the Dominican Republic is associated with a new $16 \mathrm{Sr}$ IV group phytoplasma. Plant Pathol. 57:366.

18. McCoy, R., Caudwell, A., Chang, C., Chen, T., Chiykowski, L., Cousin, M., Dale, J., de Leeuw, G., Golino, D., Hackett, K., Kirkpatrick, B., Petzold, R., Sinha, R., Sugiura, M., Whitcomb, R., Yong, I., Zhu, B., and Seemüller, E. 1989. Plant disease associated with mycoplasmalike organisms. Pages 545640 in: The Mycoplasmas. R. Whitcomb and J. Tully, eds. Academic Press, New York.

19. McCoy, R. E., Howard, F. W., Tsai, M., Donselman, H. M., Thomas, D. L., Basham, H. G., Atilano, R. A., Eskafi, F. M., Britt, L., and Collins, M. E. 1983. Lethal yellowing of palms. Univ. Florida Agric. Exp. Stn. Tech. Bull. No 834.

20. Narvaez, M., Cordova, I., Orellana, R., Harrison, N. A., and Oropeza, C 2006. First report of a lethal yellowing phytoplasma in Thrinax radiata and Cocothrinax readii palms in the Yucatan Peninsula of Mexico. Plant Pathol. 55:292.

21. Nic-Matos, J. 2007. Efecto de la presencia del amarillamiento letal en poblaciones de la palma Thrinax radiata en Yucatán. Tesis profesional. Instituto Tecnológico Superior del Estado de Yucatán.

22. Olvera-Fonseca, S. 2004. Evaluation of the bromatological potential of seeds and fruits of Sabal mexicana mart. (Arecaceae). Econ. Bot. 58:536543.

23. Quero, H., and Flores, S. 2004. Arecaceae: Taxonomía, Florística y Etnobotánica. Fascículo 23 de la colección Etnoflora Yucatanense. Universidad Autónoma de Yucatán. México.

24. Smart, C., Schneider, B., Blomquist, C., Guerra, L., Harrison, N., Ahrens, U., Lorenz, H., Seemüller, E., and Kirkpatrick, C. 1996. Phytoplasmaspecific PCR primers based on sequences of the 16S-23S rRNA spacer region. Appl. Environ. Microbiol. 62:2988-2993.

25. Tamura K., Dudley, J., Nei, M., and Kumar, S. 2007. MEGA4: Molecular Evolutionary Genetics Analysis (MEGA) software version 4.0. Mol. Biol. Evol. 24:1596-1599.

26. Thompson, J., Higgins, D., and Gibson, T. 1994. CLUSTAL W: improving the sensitivity of progressive multiple sequence alignment through sequence weighting, positions-specific gap penalties and weight matrix choice. Nucleic Acids Res. 22:4673-4680.

27. Wei, W., Davis, R., Lee, I., and Zhao, Y. 2007. Computer-simulated RFLP analysis of $16 \mathrm{~S}$ rRNA genes: identification of ten new phytoplasma groups. Int. J. Syst. Evol. Microbiol. 57:1885-1867.

28. Weintraub, P., and Beanland, L. 2006. Insect vectors of phytoplasmas. Annu. Rev. Entomol. 51:91-111.

29. Zizumbo, D., Colunga-GarcíaMarín, P., Fernández-Barrera, M., TorresHernández, N., and Oropeza, C. 2008. Mortality of Mexican coconut germplasm due to lethal yellowing. Plant Genet. Resour. Newsl. 156:23-33. 